\title{
Development of Mobile Learning Based Media for Microprocessor Engineering Subject in SMK Negeri 5 Surabaya
}

\author{
Gustav Mandigo Anggana Raras, ${ }^{a, 1, *}$, Munoto $^{\mathrm{a}, 2}$, Ekohariadi ${ }^{\mathrm{a}, 3}$ \\ ${ }^{a}$ Universitas Negeri Surabaya, Surabaya 60231, Indonesia \\ ${ }^{1}$ gustavmandigoangganararas@gmail.com; ${ }^{2}$ munoto@ unesa.ac.id; ${ }^{3}$ ekohariadi@ unesa.ac.id
}

\begin{tabular}{|c|c|}
\hline Article Info & ABSTRACT \\
\hline $\begin{array}{l}\text { Keyword: } \\
\text { Mikro-X } \\
\text { Microprocessor engineering } \\
\text { Research and development } \\
\text { Affective } \\
\text { Cognitive } \\
\text { Psychomotor }\end{array}$ & $\begin{array}{l}\text { the purpose of this research is to produce a valid teaching media for microprocessor } \\
\text { engineering subject named Mikro-X. Mikro-X can be accessed online either using } \\
\text { computer or smartphone. The development of Mikro-X is based on ten step R\&D by } \\
\text { Borg and Gall. In the experiment step two class is used, X-EDK } 1 \text { as experiment class } \\
\text { and X-EDK } 2 \text { as control class. Mikro-X is used in experiment class while conventional } \\
\text { media is used in control class. Two class is compared by their learning outcomes } \\
\text { (affective, cognitive, and psychomotor). Mikro-X has validity } 4.539 \text { (Likert scale) based } \\
\text { on four validator responses. On the experiment stage, students who use Mikro-X have } \\
\text { a higher learning outcome (affective, cognitive, and psychomotor) than students who } \\
\text { use conventional media. }\end{array}$ \\
\hline
\end{tabular}

\section{INTRODUCTION}

In this era, technology and information are rapidly developing, adaptation is needed by everyone in order to compete with global. The adaptation is also needed in the world of education. One of the adjustment that can be done in the field of education is the use of technology in teaching process. In the field of education, technology plays important roles. There are several advantages of using technology in education process, such as: (a) the freedom of time and place to learn (Beldarrain, 2006; Kim, Mims, \& Holmes, 2006), (b) increase the speed of learning and teaching process (Kim et al., 2006; Schacter, 1999), (c) students who use latest technology score higher than students who use conventional technology (Livingstone, 2012; Schacter, 1999), (d) student like their classes and show a positive attitude when suing technology (Schacter, 1999), and (e) give more effective and efficient learning in the context of student development both individually and in groups (Eschenbrenner \& Nah, 2007).

Today, the need for technology can't be separated from daily activities. Students also become one of the parties who can't be separated from the development of technological products. The average female student spends most of his time using his smartphone about 10 hours a day, whereas the male student spends 8 hours a day on his smartphone (Roberts, Yaya, \& Manolis, 2014). Mostly the student uses his smartphone to send short messages and play social media. $28.9 \%$ of high school students have experienced a smartphone addiction which interfere their lives (Kwon et al., 2013). $59.65 \%$ of male students and $74.67 \%$ of female students had been addicted to smartphone (Mok et al., 2014). Average student spends 207 minutes up to 253 minutes a day on smartphone. Some of these finding can be used as an overview of how students today spend their time by consuming mobile technology.

Table I shows information about internet users based on the operating system (OS). It appears that 3 users with the highest percentage are occupied by Windows, Android and iOS. When the access of smartphone devices, Android and iOS, combined it reach $44.95 \%$. Based on this data it can be said that global access to mobile information is high enough for both computer and smartphones.

Table II shows the market share of OS in Indonesia from February 2016 to February 2017. The majority of internet users in Indonesia using Android, while the second place using Windows OS. Based on the data can be said that the 
average internet users in Indonesia using his smartphone to get information via internet. While the second place using their computer to get information via internet.

Based on all data below, it would be better if the students use their time when surfing through the internet to develop themselves through his mobile device, computer and smartphone. When developing their self in a positive direction, Indonesian students will actively participate in achieving national educational goals. One example of a positive activity in using a mobile devices is learning the lessons taught in school through their mobile device.

Facts obtained when doing need assessment on October 26, 2016 through interviews to microprocessor engineering teacher show that there is no mobile learning-based learning media for the subject. The learning that took place using electronic school books (BSE) which majority owned by students in printed form. The basic problem with the textbook lies in its lack of mobility. Based on these with supporting information that has been described earlier then in order to improve the quality of learning on microprocessor technique subjects in SMK Negeri 5 Surabaya, Mikro-X is developed.

TABLE I. GLOBAL OPERATING SYSTEM MARKET SHARE (statcounter: GlobalStats, 2017b)

\begin{tabular}{llc}
\hline No & \multicolumn{1}{c}{ Operating System } & Percentage \\
\hline 1 & Windows & $42.63 \%$ \\
2 & Android & $32.98 \%$ \\
3 & iOS & $11.97 \%$ \\
4 & OS X & $5.1 \%$ \\
5 & Unknown & $3.49 \%$ \\
6 & Linux & $0.91 \%$ \\
7 & Other & $2.91 \%$ \\
\hline
\end{tabular}

TABLE II. INDONESIA OPERATING SYSTEM MARKET SHARE (statcounter: GlobalStats, 2017a)

\begin{tabular}{llc}
\hline No & \multicolumn{1}{c}{ Operating System } & Percentage \\
\hline 1 & Android & $55.8 \%$ \\
2 & Windows & $23.59 \%$ \\
3 & Unknown & $7.53 \%$ \\
4 & Nokia & $2.83 \%$ \\
5 & iOS & $2.8 \%$ \\
6 & BlackBerry & $2.42 \%$ \\
7 & Other & $5.03 \%$ \\
\hline
\end{tabular}

There are three advantages using Mikro-X, such as: (a) Mikro-X is based on mobile learning, (b) BSE is less portable, vice versa, Mikro-X can be accessed anywhere, and (c) material on conventional media used national standards while material on Mikro-X is based on textbooks that have international standards.

In the study, it was found that there was a normalized gain of 0.42 between pre-test (pre-test score 52.46) and post-test (post-test score 74.01) after the students use learning media based on mobile learning on physics subject (Nurohman \& Suyoso, 2013). Based on need assessment result and supported by relevant research, it is necessary to develop mobile learning-based learning media on microprocessor engineering subject.

This template, modified in MS Word 2007 and saved as a "Word 97-2003 Document" for the PC, provides authors with most of the formatting specifications needed for preparing electronic versions of their papers. All standard paper components have been specified for three reasons: (1) ease of use when formatting individual papers, (2) automatic compliance to electronic requirements that facilitate the concurrent or later production of electronic products, and (3) conformity of style throughout a conference proceedings. Margins, column widths, line spacing, and type styles are built-in; examples of the type styles are provided throughout this document and are identified in italic type, within parentheses, following the example. Some components, such as multi-leveled equations, graphics, and tables are not prescribed, although the various table text styles are provided. The formatter will need to create these components, incorporating the applicable criteria that follow.

\section{MIKRO-X}

Mikro-X is a mobile learning-based media that can be accessed through the website using both computer or smartphone and also can be accessed through the application via android.

Mikro-X consist of 10 materials which is developed based on international standardized textbooks. The materials are: (a) microprocessor development, (b) microprocessor components, (c) binary number, (d) hexadecimal number, (e) binary addition and subtraction, (f) logic gates, (g) algorithms and flowcharts, (h) assembly language, (i) Intel 8051 instruction, and (j) Intel 8051 instruction examples. These 10 materials are intended to meet the basic competencies to be achieved.

Mikro-X initial display is the login page that the student must fill in with the username and password they have. When already logged in, students can access all feature in Mikro-X such as material and exercise. Each material is supported with explanatory material and exercise question. After doing the exerises the students can also see the score. There's no display difference between Mikro-X web version with Mikro-X Android application version. In Android, Mikro-X splits into two application, for teacher and students. While the website version, both of them can directly use the same website but only distinguished by the username they use. 


\section{METHOD}

The development of Mikro-X is based on educational research and development by Borg and Gall. They state that research and development is a process used to develop new products and procedures developed in such a way as to meet the criteria of effectiveness, quality, or standard (Borg \& Gall, 2003). This research and development referring to the ten steps, such as: (a) potency and problem, (b) data collecting, (c) product design, (d) product validation, (e) product revision, (f) preliminary test, $(\mathrm{g})$ product revision, (h) field test, (i) product revision, (j) mass production.

The final product of this research is Mikro-X won't be mass produced and tested in a limited way so this research only use nine stages. The stages used are done until the field test and end with analysis and reporting.

The potential that found are: (a) teacher and students have the ability in the field of technology, (b) there are microprocessor engineering subject taught in SMK Negeri 5 Surabaya, and (c) students of X-EDK has computer and smartphones that support mobile learning. While the problems are lack of leraning media and lack of learning media based on mobile learning for microprocessor engineering subject.

Validation is done by 4 people which has competencies on their field. One of them are the microprocessor engineering subject teacher in SMK Negeri 5 Surabaya, and the rest are Universitas Negeri Surabaya lecturer. Likert five scale is used on the validation process ranged from very invalid, invalid, enough, valid, very valid. The media can be used for preliminary test after the validators say that the media is valid.

Preliminary test is done on X-EDK 3 to know whether the Mikro-X can make students get learning outcomes above the minimal score (75). On the field test, quasi-experimental design is used. The pre-test is not used with the assumption every student has the same prior knowledge for both the experimental class and the control class.

The psychological challenge is the equivalence between the experimental class and the control class, in other words the constraint between the experimental class and the control class is randomized (Campbell \& Stanley, 1996). Quasiexperimental design is used because it is not possible to randomize participants in the experimental and control class (Gay, Mills, \& Airasian, 2012). Adapted from (Gay et al., 2012), then Post-Test Only Control Group Design is used with $\mathrm{X}$-EDK 1 will be the experimental class, where will be given experimental treatment, while X-EDK 2 will be the control class.

Learning outcomes that will be analyzed consist of 3 domains, affective, cognitive, and psychomotor. Analysis of affective domain obtained through observation made by teachers using observation sheet to assess student learning activities, by dividing the observed score with maximum score then multiplied with 100 .

There are 40 items of question for assessing cognitive learning outcomes. Every item has 2.5 score. The formula is counting the correct item then multiply it with 2.5 to. While to assess psychomotor learning outcomes six items is used. Score obtained by following the scoring criteria based on the rubric.

To analyze the learning outcomes for each domain, statistical analysis is used according to the data type and using Statistical Package for the Social Sciences (SPSS) software.

\section{RESULT}

\section{A. Validation}

Validation given by the validator that consist of 3 aspects, material, illustration, and language. Material get 4.4583 average score, illustration get 4.53125 average score, and language get 4.65 average score. Overall, Mikro-X got an overall score 4.539 which is very valid. Using SPSS it is known that Cronbach's Alpha is 0.991 which means there is high internal inter-rater consistency. The revision made to Mikro-X is larger fonts used in figure caption.

\section{B. Preliminary Test}

Mikro-X is used for 5 meeting with each meeting for 90 minutes and at the end of the final meeting, post-test is conducted to determine the result of learning outcomes.

Affective learning result obtained from the observation of student behavior when the learning activities take place. One sample t-test is used to analyze affective learning result data. Using SPSS obtained Sig. (2-tailed) value 0.000 which is less than 0.01. So the decision is to accept alternative hypothesis which is the average affective value of students X-EDK 3 more than minimum score.

Cognitive learning result was obtained from the cognitive post-test. One sample t-test is used to analyze the data. Using SPSS obtained Sig. (2-tailed) value 0.000 which is less than 0.01 . So the decision is to accept alternative hypothesis which is the average cognitive value of students X-EDK 3 more than minimum score.

Psychomotor learning result was obtained from the psychomotor post-test. One sample t-test is used to analyze the psychomotor learning result data. Using SPSS obtained Sig. (2-tailed) value 0.000 which is less than 0.01 . So the decision is to accept alternative hypothesis which is the average psychomotor value of students X-EDK 3 more than minimum score.

\section{Field Test}

Field test were conducted by differentiating the use of media used in teaching microprocessor engineering subject. Experimental class using Mikro-X, while control class using conventional media. At the end of the meeting, post test was done.

The affective learning outcomes data were analyzed using Mann-Whitney U Test. The value of Mann Whitney $U$ is 63.500 with Asymp. Sig. (2-tailed) 0.000 which is less than 0.01 . So the decision is to accept alternative hypothesis which is the affective learning outcomes for the experimental class is higher than the control class very significantly. 
The cognitive learning outcomes data also analyzed using Mann-Whitney $U$ Test. The value of Mann Whitney $U$ is 173.500 with Asymp. Sig. (2-tailed) 0.000 which is less than 0.01 . So the decision is to accept alternative hypoothesis which is the cognitive learning outcomes for the experimental class is higher than the control class very significantly.

The psychomotor learning outcomes data also analyzed using Mann-Whitney U Test. The value of Mann Whitney U is 183.000 with Asymp. Sig. (2-tailed) 0.000 which is less than 0.01 . So the decision is to accept alternative hypothesis which is the psychomotor learning outcomes for the experimental class is higher than the control class very significantly.

\section{CONCLUSION}

Mikro-X which is developed is a valid learning media based on mobile learning. Student who use Mikro-X score higher than student who use conventional learning media on affective, cognitive and psychomotor learning outcomes.

\section{References}

Beldarrain, Y. (2006). Distance education trends: Integrating new technologies to foster student interaction and collaboration. Distance Education, 27(2), 139-153.

Borg, W. R., \& Gall, M. D. (2003). Educational research an introduction. New York: Longman Publishing.

Campbell, D. T., \& Stanley, J. C. (1996). Experimental and quasiexperimental designs for research. Chicago: Rand McNally.

Eschenbrenner, B., \& Nah, F. F. H. (2007). Mobile technology in education: uses and benefits. International Journal of Mobile Learning and Organisation, 1(2), 159-183.

Gay, L. R., Mills, G. E., \& Airasian, P. W. (2012). Educational research: Competencies for analysis and applications. New Jersey: Pearson Education, Inc.

Kim, S. H., Mims, C., \& Holmes, K. P. (2006). An introduction to current trends and benefits of mobile wireless technology use in higher education. AACE Journal, 14(1), 77-100.

Kwon, M., Lee, J. Y., Won, W. Y., Park, J. W., Min, J. A., Hahn, C., ... Kim, D. J. (2013). Development and validation of a smartphone addiction scale (SAS). PloS One, 8(2), e56936.

Livingstone, S. (2012). Critical reflections on the benefits of ICT in education. Oxford Review of Education, 38(1), 9-24.

Mok, J. Y., Choi, S. W., Kim, D. J., Choi, J. S., Lee, J., Ahn, H., ... Song, W. Y. (2014). Latent class analysis on internet and smartphone addiction in college students. Neuropsychiatric Disease and Treatment, 10, 817.

Nurohman, S., \& Suyoso, S. (2013). Pengembangan aplikasi physics mobile learning pada gadget berplatform android guna meningkatkan akses belajar di era digital. Yogyakarta.

Roberts, J., Yaya, L., \& Manolis, C. (2014). The invisible addiction: Cellphone activities and addiction among male and female college students. Journal of Behavioral Addictions, 3(4), 254-265.

Schacter, J. (1999). The impact of education technology on student achievement: What the most current research has to say. Santa
Monica: Miken Exchange on Education Technology.

statcounter: GlobalStats. (2017a). Operating System Market Share Indonesia: Feb 2016-Feb 2017. Retrieved November 21, 2017, from http://gs.statcounter.com/os-market-share/all/indonesia/\#monthly201602-201702

statcounter: GlobalStats. (2017b). Operating System Market Share Worldwide: Feb 2016-Feb 2017. Retrieved November 16, 2017, from http://gs.statcounter.com/os-market-share\#monthly-201602-201702 